\title{
Association study of newly identified age-related macular degeneration susceptible loci SOD2, MBP, and C8orf42 in Han Chinese population
}

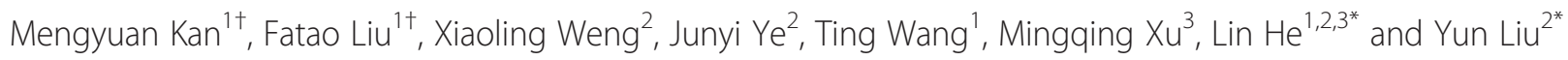

\begin{abstract}
A recent genome-wide association study has reported three newly identified susceptible loci (rs2842992 near the gene SOD2, rs1789110 near the gene MBP and rs722782 near the gene C8orf42) to be associated with the geographic atrophy subtype of age-related macular degeneration in European-descent population. We investigated the correlation between these variants and advanced age-related macular degeneration for the first time in a Han Chinese cohort; however, no evidence supports these previously identified loci contribute to advanced age-related macular degeneration susceptibility in Chinese population.
\end{abstract}

Keywords: Age-related macular degeneration, Han Chinese population, Association study

\section{Letters to the editor}

Age-related macular degeneration (AMD) is a late-onset neurodegenerative disease, which is the major cause of visual impairment and blindness in adults aged 55 years or older [1]. AMD is characterized with formation of choroidal drusen, yellow deposits between the retinal pigment epithelium (RPE) and underlying choroid in the early stage. The progression of AMD in an advanced stage (advanced AMD) can be classified as atrophy of the RPE (geographic atrophy (GA), or dry AMD), or as the growth of abnormal choroidal vessels under the retina (choroidal neovascularization (CNV), or wet AMD) $[2,3]$. Previous studies showed that the estimated prevalence of advanced AMD was 1.0\% in Chinese compared to $0.6 \%$ in Europeans [4] and CNV form was more common in Chinese individuals $[4,5]$. Genetic studies often combined GA and CNV cases as overall advanced AMD to find the heritable loci and some subgroup analysis also suggested that these two subtypes of advanced

\footnotetext{
*Correspondence: helin@bio-x.cn; superliuyun@gmail.com

${ }^{\dagger}$ Equal contributors

IInstitute for Nutritional Sciences, Shanghai Institutes for Biological Sciences, Chinese Academy of Sciences, Graduate School of the Chinese Academy of Sciences, Shanghai 200031, P. R. China

${ }^{2}$ Institutes of Biomedical Sciences, Fudan University, Ming Dao Building, 138

Yi Xue Yuan Road, Shanghai 200032, P. R. China

Full list of author information is available at the end of the article
}

AMD might share common genetic risk factors [6-10]. Recently, a genome-wide association study (GWAS) has found several single nucleotide polymorphisms (SNPs) specifically associated with GA subtype or CNV subtype in European-descent population [11]. We aimed to investigate SNPs which were correlated with GA (rs2842992 near SOD2 $\left(\mathrm{P}=3.4 \times 10^{-7}\right)$; rs1789110 near $M B P\left(\mathrm{P}=4.2 \times 10^{-7}\right)$ and rs722782 near C8orf42 $\left.\left(\mathrm{P}=1.9 \times 10^{-6}\right)\right)$ in a Han Chinese cohort, given a sample with higher proportion of GA subtype (37.7\% for GA versus $26.5 \%$ for CNV). Due to the small sample size for each subtype (77 GA cases, $54 \mathrm{CNV}$ cases and 73 advanced AMD cases lacking of further subtype information), we combined the cases as a whole and analyzed the three SNPs to determine any possible effect on advanced AMD risk in Chinese population.

204 AMD cases were recruited from the Putuo People's Hospital in Zhoushan, China and 384 unrelated healthy controls were enrolled from the same region. AMD clinical diagnosis was defined strictly in accordance with the International Classification of Age-Related Maculopathy and Macular Degeneration [2]. A standard informed consent was established following the guidelines of the Helsinki Declaration and approved by the ethics committee of the Shanghai Institute for Biological Sciences. All the participants obtained and signed the consent. A demographic summary of the phenotypic information was shown in Table 1. High-molecular-weight genomic 
Table 1 Characteristics of the participants

\begin{tabular}{|c|c|c|}
\hline Characteristics & Case & Control \\
\hline$N$ & 204 & 384 \\
\hline GA subtype (\%) & 37.7 & / \\
\hline CNV subtype (\%) & 26.5 & / \\
\hline AMD diagnosis (\%) & 35.3 & / \\
\hline Female (\%) & 44.2 & 55.9 \\
\hline Age (years) & $74.9 \pm 7.0(53-89)$ & $67.6 \pm 6.6(52-86)$ \\
\hline $\begin{array}{l}\text { Abbreviations: GA geoo } \\
\text { Data are presented as } \\
\text { to maximum). } \\
\text { aThese cases were dias } \\
\text { subtype information. }\end{array}$ & $\begin{array}{l}\text { rophy, CNV choroid } \\
\pm \text { standard deviat } \\
\text { ith AMD, but we cc }\end{array}$ & $\begin{array}{l}\text { cularization. } \\
\text { ange (minimum } \\
\text { cquire specific }\end{array}$ \\
\hline
\end{tabular}

DNA was prepared from venous blood using standard phenol-chloroform extraction. The variants of interest were genotyped by TaqMan SNP genotyping assay (Life Technologies, Carlsbad, California, USA). Genotype data were obtained in more than $93 \%$ of the DNA samples and 38 replicated quality controls were genotyped with $100 \%$ concordance. We calculated Hardy-Weinberg equilibrium for each variant based on an exact test [12] and no departures from the equilibrium were observed in controls $(P>0.05)$. We evaluated the association between alleles and AMD in terms of odds ratios (ORs), 95\% confidence intervals (CIs), and corresponding $\mathrm{P}$ values based on Fisher's exact test. We further assessed the association between genotypes and AMD using logistic regression assuming an additive model. As we found significant difference of age distributions between cases and controls $(\mathrm{P}<0.001)$, we also analyzed the genotypic associations with adjustment for age. All of the statistical tests were carried out using the $\mathrm{R}$ software package (http://www. r-project.org/), and a P-value $<0.05$ was defined as statistical significance. Statistic powers was post hoc calculated using the G*Power program, based on goodness-of-fit test [13].

The allelic and genotypic association results for the selected variants (rs2842992, rs1789110 and rs722782) were shown in Table 2. We did not find evidence of association between these variants and advanced AMD either in allele level $(\mathrm{P}=0.277$ for $\mathrm{rs} 2842992 ; \mathrm{P}=0.850$ for rs1789110 and $\mathrm{P}=0.281$ for rs722782) or genotype level $(\mathrm{P}=0.266$ for rs2842992; $\mathrm{P}=0.798$ for $\mathrm{rs} 1789110$ and $\mathrm{P}=0.279$ for rs722782) in our samples. Even after correction for age, the associations with advanced AMD still remained insignificant $(\mathrm{P}=0.661$ for $\mathrm{rs} 2842992$; $\mathrm{P}=0.537$ for $\mathrm{rs} 1789110$ and $\mathrm{P}=0.080$ for $\mathrm{rs} 722782$ ). Moreover, we observed little heterogeneity between GA cases and non-GA cases as the effective allele frequencies are very close in these two groups (Table 2).

One explanation for the failure to replicate the associations in our study could be the phenotypic difference between GA and CNV of advanced AMD: GA is characterized by the loss of normal RPE cells in a discrete area of the macula ( $\geq 175 \mu \mathrm{m}$ in diameter) with a sharp border and visible choroidal vessels in the absence of $\mathrm{CNV}$, which has some clinic aspects in common with chloroquine retinopathy [14]; while CNV is featured by haemorrhagic detachment of RPE and presence of subretinal fibrous, with the development of neovascularisation towards the macula resulting in leaking fluid or blood $[2,3]$. As these loci were identified to be associated with GA alone by Sobrin et al. [11], while we used overall advanced AMD which included both GA and CNV cases, it is possible that the associations were masked by the phenotypic heterogeneity of mixture of GA and $\mathrm{CNV}$ in our samples. Another explanation for the negative findings could be the low statistical powers in our study $(21.7 \%$ for rs2842992, 5.5\% for rs 1789110 and $21.4 \%$ for rs722782), which indicated inadequate powers to detect potential associations. However, if the disease risk could reach a modest effect (OR, 0.70) as reported by Sobrin et al. [11], we found the sample size had $>90 \%$ power for these variants to detect the association. Furthermore, in previous GWAS study [11], these loci were reported to be highly associated with GA ( $P$ values ranging from $10^{-6}$ to $\left.10^{-7}\right)$, but none of them reached the generally used genome-wide threshold $\left(\mathrm{P}=5.0 \times 10^{-8}\right)$, thus these loci were only considered as suggestive association signals by the authors. Meanwhile, the discrepancies of genetic structures and disease prevalence among populations may also account for the inconsistency.

Among these three AMD genetic loci (SOD2, MBP and C8orf42) [11], SOD2 was previously studied with a common missense variant rs 4880 which showed associations with AMD in Japanese population [15], while this finding was inconsistent with follow-up studies [16-18]. SOD2 gene encodes a mitochondrial enzyme, which is involved in the detoxification of superoxide free radicals. Oxidative damage to the retina, RPE or choroid complex is implicated for the development of AMD [19,20]. Functional studies demonstrated SOD2 (superoxide dismutase 2) protects against reactive oxygen speciesinduced oxidative damage in mouse RPE [20,21], indicating a role in AMD pathogenesis. Aside from SOD2, currently there is no other genetic evidence for $M B P$ and C8orf42 loci contributing to AMD, and whether these genes have functional potentiality to AMD pathogenesis remains to be elucidated.

In summary, the SNPs on genetic loci $S O D 2, M B P$ and C8orf42, which predisposed to GA risk in European population, were not found significantly associated with advanced AMD in a Chinese cohort. Additional studies with larger sample size and more makers are important to clarify whether these loci confer a risk of overall advanced AMD or AMD subtypes in Chinese population. 
Table 2 Allelic and genotypic associations between three selected SNPs and AMD

\begin{tabular}{|c|c|c|c|c|c|c|c|c|c|c|c|c|c|c|}
\hline \multicolumn{4}{|c|}{ SNP information } & \multicolumn{6}{|c|}{ Allelic associations } & \multicolumn{5}{|c|}{ Genotypic associations } \\
\hline $\begin{array}{c}\text { dbSNP } \\
\text { ID }\end{array}$ & Gene & chr:pos & Location & Alleles $^{a}$ & \multicolumn{4}{|c|}{ Effective allele frequency } & $\begin{array}{c}\text { value }^{\mathrm{b}} \\
\text { OR }(95 \% \mathrm{Cl})\end{array}$ & \multicolumn{3}{|c|}{ Genotypic distributions } & $\begin{array}{c}\text { P value }^{c} \\
\text { OR }(95 \% \mathrm{Cl})\end{array}$ & $\begin{array}{c}\text { P value }{ }^{d} \\
\text { OR }(95 \% \mathrm{Cl})\end{array}$ \\
\hline \multirow{2}{*}{ rs2842992 } & & & & & & & & & & & & & 0 & 060 \\
\hline & & & & & Control & 0.558 & Non-GA case & 0.508 & $0.87(0.67-1.13)$ & & Control & $109 / 165 / 69$ & $0.87(0.67-1.12)$ & $0.93(0.68-1.28)$ \\
\hline \multirow[t]{2}{*}{ rs1789110 } & $M B P$ & $18: 74859044$ & Intergenic & $\mathrm{A} / \mathrm{C}$ & Case & 0.542 & GA case & 0.533 & 0.850 & $\mathrm{AA} / \mathrm{AC} / \mathrm{CC}$ & Case & $55 / 107 / 38$ & 0.798 & 0.537 \\
\hline & & & & & Control & 0.535 & Non-GA case & 0.548 & $1.03(0.80-1.33)$ & & Control & 100/171/76 & $1.03(0.80-1.33)$ & $1.10(0.81-1.51)$ \\
\hline \multirow[t]{2}{*}{ rs722782 } & C80rf42 & $8: 516479$ & Intergenic & $\mathrm{A} / \mathrm{C}$ & Case & 0.473 & GA case & 0.471 & 0.281 & $\mathrm{AA} / \mathrm{AC} / \mathrm{CC}$ & Case & $43 / 92 / 53$ & 0.279 & 0.080 \\
\hline & & & & & Control & 0.508 & Non-GA case & 0.475 & $0.87(0.67-1.12)$ & & Control & 97/177/91 & $0.87(0.68-1.12)$ & $0.76(0.56-1.03)$ \\
\hline
\end{tabular}

Abbreviations: chr:pos chromosome:position, $\mathrm{OR}$ odds ratio, $\mathrm{Cl}$ confidence interval.

aEffective alleles are indicated in bold type, and odds ratios were calculated based on this allele.

${ }^{\mathrm{b}} \mathrm{ORs}, 95 \% \mathrm{Cls}$ and $\mathrm{P}$ values were calculated based on Fisher's exact test.

'ORs, 95\% Cls and P values were calculated using logistic regression, assuming the additive model.

${ }^{d} \mathrm{ORs}, 95 \% \mathrm{Cls}$ and $\mathrm{P}$ values were calculated using logistic regression, assuming the additive model with adjustment for age. 


\section{Abbreviations}

AMD: Age-related macular degeneration; RPE: Retinal pigment epithelium GA: Geographic atrophy; CNV: Choroidal neovascularization; SNP: Single nucleotide polymorphism; GWAS: Genome-wide association study; OR: Odds ratios; Cl: Confidence interval; SOD2: Superoxide dismutase 2.

\section{Competing interests}

The authors declare no competing interests.

\section{Authors' contributions}

$Y L$ and $L H$ conceived the study; MK conducted the experiments, analyzed the data, and drafted the manuscript; FL analyzed the data; XW and TW conducted the experiments; MX revised the draft. All the authors have read and approved the final manuscript.

\section{Acknowledgements}

This work was supported by the 973 Program (2010CB529600, 2011CB504000), the National Key Technology R\&D Program (2012BAI01B09), and the National Natural Science Foundation of China (31200954, 81121001, 81361120389). We specially thank Dr. Dingguo Qian from Department of Ophthalmology, Putuo Peoples' Hospital, Zhoushan, China, who helped to collect the study subjects and provide clinical diagnosis for AMD.

\section{Author details}

'Institute for Nutritional Sciences, Shanghai Institutes for Biological Sciences, Chinese Academy of Sciences, Graduate School of the Chinese Academy of Sciences, Shanghai 200031, P. R. China. Institutes of Biomedical Sciences, Fudan University, Ming Dao Building, 138 Yi Xue Yuan Road, Shanghai 200032, P. R. China. ${ }^{3}$ Bio-X Institutes, Key Laboratory for the Genetics of Developmental and Neuropsychiatric Disorders (Ministry of Education), Shanghai Jiao Tong University, Shanghai 200030, P.R. China.

Received: 25 February 2014 Accepted: 18 March 2014

Published: 25 March 2014

\section{References}

1. Klein R, Cruickshanks KJ, Nash SD, Krantz EM, Nieto FJ, Huang GH, Pankow $J S$, Klein BE: The prevalence of age-related macular degeneration and associated risk factors. Arch Ophthalmol 2010, 128:750-758.

2. Bird AC, Bressler NM, Bressler SB, Chisholm IH, Coscas G, Davis MD, de Jong PT, Klaver CC, Klein BE, Klein R, Mitchell P, Sarks JP, Sarks SH, Soubrane G, Taylor HR, Vingerling JR: An international classification and grading system for age-related maculopathy and age-related macular degeneration. The International ARM Epidemiological Study Group. Surv Ophthalmol 1995, 39:367-374.

3. Coleman HR, Chan CC, Ferris FL 3rd, Chew EY: Age-related macular degeneration. Lancet 2008, 372:1835-1845.

4. Klein R, Klein BE, Knudtson MD, Wong TY, Cotch MF, Liu K, Burke G, Saad MF, Jacobs DR Jr: Prevalence of age-related macular degeneration in 4 racial/ ethnic groups in the multi-ethnic study of atherosclerosis. Ophthalmology 2006, 113:373-380

5. Vinding T, Appleyard M, Nyboe J, Jensen G: Risk factor analysis for atrophic and exudative age-related macular degeneration. An epidemiological study of 1000 aged individuals. Acta Ophthalmol (Copenh) 1992, 70:66-72.

6. Fagerness JA, Maller JB, Neale BM, Reynolds RC, Daly MJ, Seddon JM: Variation near complement factor I is associated with risk of advanced AMD. Eur J Hum Genet 2009, 17:100-104.

7. Jakobsdottir J, Conley YP, Weeks DE, Mah TS, Ferrell RE, Gorin MB: Susceptibility genes for age-related maculopathy on chromosome 10q26. Am J Hum Genet 2005, 77:389-407.

8. Maller J, George S, Purcell S, Fagerness J, Altshuler D, Daly MJ, Seddon JM: Common variation in three genes, including a noncoding variant in $\mathrm{CFH}$, strongly influences risk of age-related macular degeneration. Nat Genet 2006, 38:1055-1059.

9. Maller JB, Fagerness JA, Reynolds RC, Neale BM, Daly MJ, Seddon JM: Variation in complement factor 3 is associated with risk of age-related macular degeneration. Nat Genet 2007, 39:1200-1201.

10. Rivera A, Fisher SA, Fritsche LG, Keilhauer CN, Lichtner P, Meitinger T, Weber BH: Hypothetical LOC387715 is a second major susceptibility gene for age-related macular degeneration, contributing independently of complement factor $\mathrm{H}$ to disease risk. Hum Mol Genet 2005, 14:3227-3236.
11. Sobrin L, Ripke S, Yu Y, Fagerness J, Bhangale TR, Tan PL, Souied EH, Buitendijk GH, Merriam JE, Richardson AJ, Raychaudhuri S, Reynolds R, Chin KA, Lee AY, Leveziel N, Zack DJ, Campochiaro P, Smith RT, Barile GR, Hogg RE, Chakravarthy U, Behrens TW, Uitterlinden AG, van Duijn CM, Vingerling JR, Brantley MA Jr, Baird PN, Klaver CC, Allikmets R, Katsanis N, et al: Heritability and genome-wide association study to assess genetic differences between advanced age-related macular degeneration subtypes. Ophthalmology 2012, 119:1874-1885.

12. Wigginton JE, Cutler DJ, Abecasis GR: A note on exact tests of Hardy-Weinberg equilibrium. Am J Hum Genet 2005, 76:887-893.

13. Faul F, Erdfelder E, Lang AG, Buchner A: G*Power 3: a flexible statistical power analysis program for the social, behavioral, and biomedical sciences. Behav Res Methods 2007, 39:175-191.

14. Ma X, Yan L, He L, He D, Lu H: Ocular fundus manifestation of two patients following long-term chloroquine therapy: a case report. Diagn Pathol 2010, 5:20.

15. Kimura K, Isashiki Y, Sonoda S, Kakiuchi-Matsumoto T, Ohba N: Genetic association of manganese superoxide dismutase with exudative age-related macular degeneration. Am J Ophthalmol 2000, 130:769-773.

16. Esfandiary H, Chakravarthy U, Patterson C, Young I, Hughes AE: Association study of detoxification genes in age related macular degeneration. Br J Ophthalmol 2005, 89:470-474.

17. Gotoh N, Yamada R, Matsuda F, Yoshimura N, lida T: Manganese superoxide dismutase gene (SOD2) polymorphism and exudative age-related macular degeneration in the Japanese population. Am J Ophthalmol 2008, 146:146. author reply 146-147.

18. Kondo N, Bessho H, Honda S, Negi A: SOD2 gene polymorphisms in neovascular age-related macular degeneration and polypoidal choroidal vasculopathy. Mol Vis 2009, 15:1819-1826

19. Beatty $\mathrm{S}$, Koh H, Phil M, Henson D, Boulton M: The role of oxidative stress in the pathogenesis of age-related macular degeneration. Surv Ophthalmol 2000, 45:115-134.

20. Justilien V, Pang JJ, Renganathan K, Zhan X, Crabb JW, Kim SR, Sparrow JR, Hauswirth WW, Lewin AS: SOD2 knockdown mouse model of early AMD. Invest Ophthalmol Vis Sci 2007, 48:4407-4420.

21. Kasahara $E$, Lin LR, Ho YS, Reddy VN: SOD2 protects against oxidationinduced apoptosis in mouse retinal pigment epithelium: implications for age-related macular degeneration. Invest Ophthalmol Vis Sci 2005, 46:3426-3434

doi:10.1186/1746-1596-9-73

Cite this article as: Kan et al:: Association study of newly identified age-related macular degeneration susceptible loci SOD2, MBP, and C8orf42 in Han Chinese population. Diagnostic Pathology 2014 9:73.

\section{Submit your next manuscript to BioMed Central and take full advantage of:}

- Convenient online submission

- Thorough peer review

- No space constraints or color figure charges

- Immediate publication on acceptance

- Inclusion in PubMed, CAS, Scopus and Google Scholar

- Research which is freely available for redistribution

Submit your manuscript at www.biomedcentral.com/submit
C) BioMed Central 